\title{
Synthesis and Stereochemical Assignment of Methyl 3-(3-hydroxyphenoxy)acrylate via cis-trans Photoisomerization
}

\author{
Mirela Inês de Sairre, Luiz Felipe N. Araújo, Rosangela da Silva, Paulo Marcos Donate,* \\ Cristina A. Silvério and Laura T. Okano
}

Departamento de Química, Faculdade de Filosofia, Ciências e Letras de Ribeirão Preto da Universidade de São Paulo, Avenida Bandeirantes 3900, 14040-901 Ribeirão Preto - SP, Brazil

\begin{abstract}
3-(3-Hidroxi-fenoxi)acrilato de metila (2), um novo e importante material de partida para inúmeras reações e um precursor potencial do produto natural 3-(3-hidroxi-fenoxi)-2-propenal (1), foi sintetizado a partir de resorcinol e propiolato de metila. A configuração trans da dupla ligação presente no composto 2 foi confirmada através de uma reação de fotoisomerização.
\end{abstract}

Methyl 3-(3-hydroxyphenoxy)acrylate (2), a new and important starting material for several reactions and a potential precursor of the natural product 3-(3-hydroxyphenoxy)-2-propenal (1), was synthesized from resorcinol and methyl propiolate. The trans configuration of the double bond present in $\mathbf{2}$ was confirmed through a photoisomerization reaction.

Keywords: methyl 3-(3-hydroxyphenoxy)acrylate, 3-(3-hydroxyphenoxy)-2-propenal, photoisomerization reaction, synthesis

\section{Introduction}

The phytochemistry of Artemisia has been extensively investigated in the last few years. ${ }^{1,2}$ This medicinal plant produces highly oxygenated sesquiterpenes that can be applied to the treatment of malaria. ${ }^{1}$ Examples of such compounds are the potent anti-malarial drug artemisinin and its derivatives, which can be isolated from the aerial parts of Artemisia annua L. ${ }^{2}$ However, their natural occurrence is very low, which has led to intensive research efforts toward the production of new biotechnological strategies or synthetic ways to enhance their production. ${ }^{1,2}$ Apart from highly oxygenated sesquiterpenes, several other aromatic compounds such as coniferaldehyde derivatives and 5-alkyl resorcinols have also been isolated from Artemisia aпnиa L. ${ }^{3}$ It has also been reported ${ }^{4}$ that Artemisia subdigitata Mattf. contains flavonoids, coumarins, substituted phenols, and a number of compounds that have not been previously described, like 3-(3-hydroxyphenoxy)-2-propenal (1) shown in Figure 1.

*e-mail: pmdonate@usp.br
The cis to trans photoisomerization of organic molecules has found large application in biochemical processes, ${ }^{5}$ e.g., the photon signal transduction of rhodopsin in the visual process. ${ }^{6}$ The interconversion of cis- to trans-olefins is a thermodynamically spontaneous process but, in the absence of radical initiators, this conversion usually occurs very slowly at room temperature. Light absorption by olefins leads to a photoisomerization process. Sometimes, the more stable isomer can be transformed into the less stable one upon light irradiation. This process can proceed either via the $\pi, \pi^{*}$ singlet $\left(\mathrm{S}_{1}\right)$ or triplet $\left(\mathrm{T}_{1}\right)$ excited states. Any of the isomers can be formed when the molecule returns to the ground state $\left(\mathrm{S}_{0}\right)$, because both the $\mathrm{S}_{1}$-p state and the $\mathrm{T}_{1}$ - $\mathrm{p}$ state have a perpendicular geometry. The barrier of the isomerization process is lowered when there is conjugation of the carbon-carbon double bond with a heteroatomic $\pi$-system. ${ }^{5}$ The mechanism of acrylate isomerization is dependent on the presence of other compounds in the solution, such as nucleophiles ${ }^{7}$ or radicals. ${ }^{8}$

The goal of this paper is to report a short synthetic route for the preparation of methyl 3-(3-hydroxyphenoxy) acrylate (2), a new and potential precursor of the natural product 3-(3-hydroxyphenoxy)-2-propenal (1) isolated 
<smiles>O=C/C=C/Oc1cccc(O)c1</smiles>

1

Figure 1. A natural product from Artemisia subdigitata Mattf.

from Artemisia species. Because it was not possible to obtain the correct configuration of the acrylate double bond in the ester derivative $\mathbf{2}$ from the magnitude of the vicinal coupling constant of the NMR spectra, a simple cis-trans photoisomerization experiment was used to produce the cis isomer. The photoisomerization reaction was followed by NMR and UV-Vis spectroscopic measurements from time to time. Determination of the configuration of the initial synthetic natural product and an estimation of the trans-cis interconversion rate were obtained from the experimental data.

\section{Results and Discussion}

Compound 2 was synthesized from commercial resorcinol (1,3-dihydroxybenzene). Initially, resorcinol and triphenylphosphine were dissolved in dichloromethane. A solution of methyl propiolate in dichloromethane was slowly added to this solution, and the mixture was kept under stirring for $24 \mathrm{~h}$ at room temperature. ${ }^{9}$ The residue was purified by column chromatography on silica gel. Analysis by ${ }^{1} \mathrm{H}$ and ${ }^{13} \mathrm{C}$ NMR spectroscopy revealed that the product was a mixture of compounds $\mathbf{2}$ and $\mathbf{3}$ with yields of $65 \%$ and $15 \%$, respectively (Scheme 1).

Yavari, Hekmat-Shoar and Zonousi ${ }^{9}$ performed reactions between substituted phenols and dimethyl<smiles>Oc1cccc(O)c1</smiles>

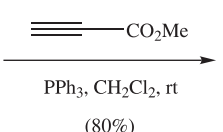<smiles>COC(=O)/C=C/Oc1cccc(O)c1</smiles><smiles>COC(=O)/C=C/Oc1cccc(O/C=C/C(=O)OC)c1</smiles>

3

Scheme 1. Synthesis of compounds 2 and $\mathbf{3 .}$

acetylenedicarboxylate (DMAD) in the presence of triphenylphosphine under reflux in dichloromethane, and they obtained coumarins in good yields. They assumed that the addition of triphenylphosphine to the acetylenic ester followed by protonation would result in an intermediate vinyltriphenylphosphonium salt. The formation of coumarins should occur by an eletrophilic attack of this vinyltriphenylphosphonium species on the aromatic ring and further intramolecular lactonization.

It has been reported ${ }^{10}$ that the coumarin ring could not be produced in a reaction similar to the one described in this work, but it was produced through a process carried out under milder conditions. An unusual $O$-conjugate addition reaction of the phenol to methyl propiolate must have occurred in our case, ${ }^{11-13}$ furnishing compounds $\mathbf{2}$ and $\mathbf{3}$. Usually, the $O$-conjugate addition is not very common for most enolate conjugate addition reactions. However, in our work, $O$-addition was especially favored because the

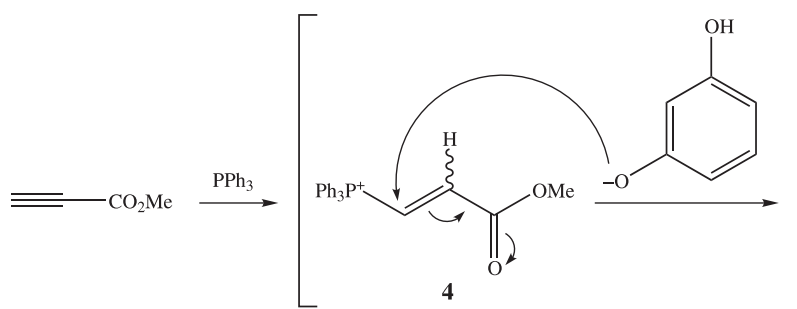

4<smiles>CCC(CC(=O)OC)Oc1cccc(O)c1</smiles><smiles>COC(=O)/C=C/Oc1cccc(O)c1</smiles>

Scheme 2. Proposed reaction mechanism for the preparation of compound 2. 
nucleophile is stabilized and the electrophile has a hard leaving group.

A reasonable mechanism for this addition reaction $9,11-13$ is shown in Scheme 2. The first step of the process involves a Michael addition of triphenylphosphine to the propiolate, thus generating an active phosphonium intermediate (4). This latter species undergoes a subsequent addition of the phenoxide in a 1,4-fashion, followed by elimination of triphenylphosphine, to afford compound 2.

Derivative 2 was prepared and its structure was identified spectroscopically. However, the determination of the alkene configuration was not possible. Typically, the stereochemical assignment of the acrylate double bond is based on the magnitude of the vicinal coupling constant $(J)$ of the corresponding hydrogens in the ${ }^{1} \mathrm{H}$ NMR spectra. The range for trans and cis isomers are, respectively, 12 to 18, and 6 to $12 \mathrm{~Hz}$. The value measured for compound 2 was $12.1 \mathrm{~Hz}$, making an unequivocal attribution extremely difficult. ${ }^{14}$

Therefore, in order to correctly assign the stereochemistry of the double bond of compound $\mathbf{2}$, we carried out a photoisomerization reaction (Scheme 3). The photoisomerization experiment was carried out in a rotating "merry-goround" reactor using a $400 \mathrm{~W}$ medium pressure mercury lamp. ${ }^{15}$ A solution of $\mathbf{2}$ was prepared in deuterochloroform, and placed into two quartz cuvettes. The first cuvette was a resonance tube and the second one a UV-Vis spectroscopic cell. Both quartz cuvettes were inserted into the photoreactor. At appropriate time intervals, the rotating "merry-goround" was stopped; the cuvettes were withdrawn from the reactor and allowed to cool down to room temperature. The ${ }^{1} \mathrm{H}$ NMR and UV-Vis spectra were registered. Then both cuvettes were replaced at the same time into the photoreactor and the irradiation process was resumed.
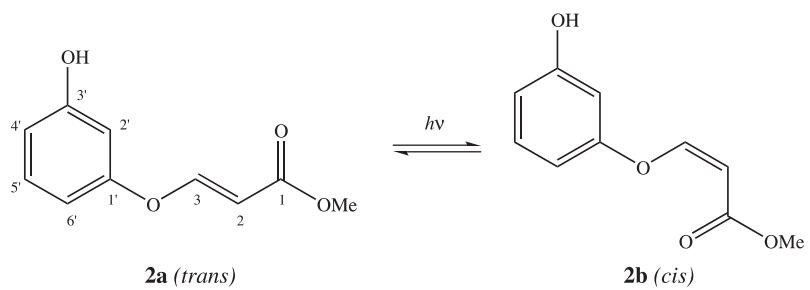

Scheme 3. Photoisomerization of compound 2.

The UV absorption spectra of the trans and cis isomers of compound 2 (Figure 2) are very similar, so very little information could be obtained from the spectrophotometric analysis.

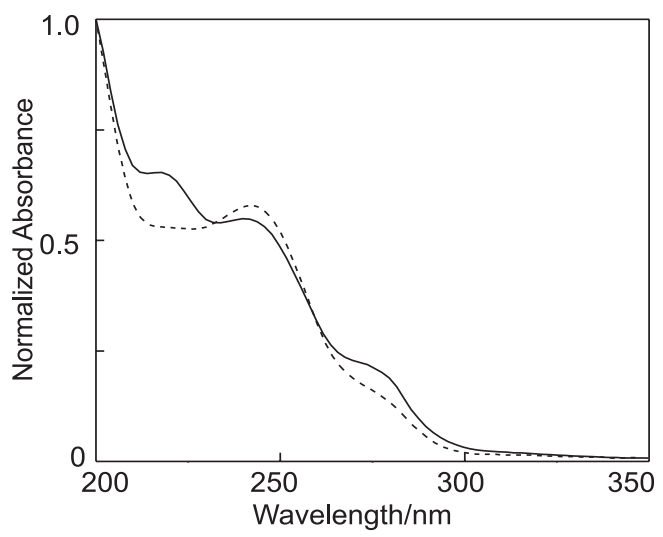

Figure 2. UV spectra of compounds 2 (trans dotted line and cis full line) in acetonitrile.

However, after $12 \mathrm{~h}$ of irradiation, the formation of isomer $\mathbf{2 b}$ was observed in the ${ }^{1} \mathrm{H}$ NMR with $25 \%$ yield (Figure 3).

Figure $3 \mathrm{~A}$ shows the ${ }^{1} \mathrm{H}$ NMR spectrum of compound 2a before the irradiation, while Figure $3 \mathrm{~B}$ reveals the appearance of a new set of NMR signals after $12 \mathrm{~h}$ of

(A)

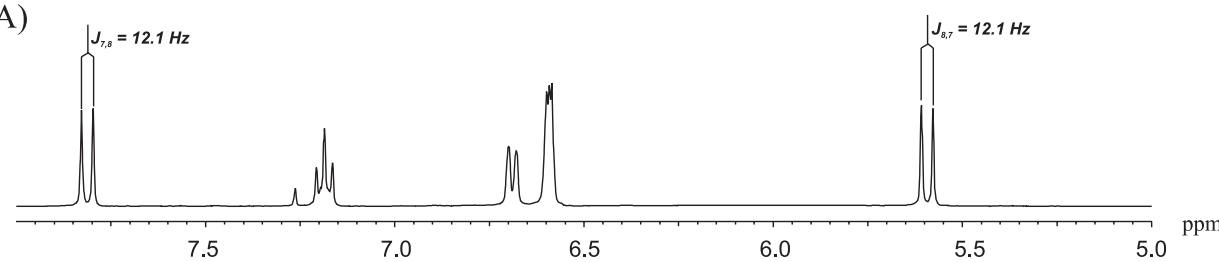

(B)

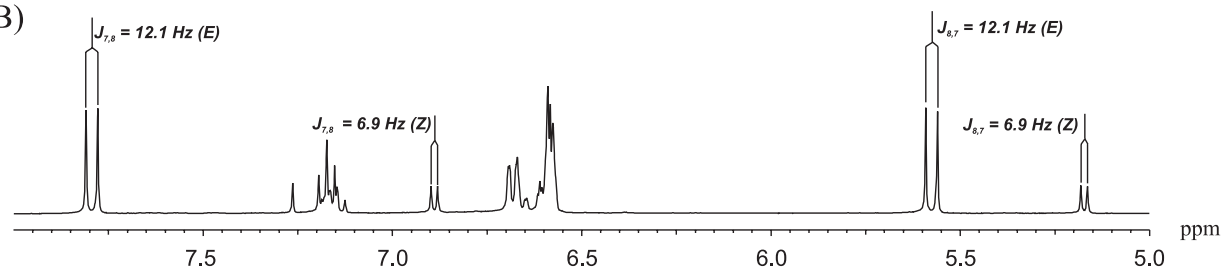

Figure 3. ${ }^{1} \mathrm{H}$ NMR spectra: (A) Isomer 2a; (B) Mixture of isomers $(\mathbf{2 a}+\mathbf{2 b})$, after 12 h of irradiation. 
irradiation. The $J$ values measured between $\mathrm{H}-2$ and $\mathrm{H}-3$ (Scheme 3) show that the double bond of the isomer $\mathbf{2 b}$ formed after irradiation has a cis configuration $(J 6.9 \mathrm{~Hz})$, so the double bond of compound $2 \mathbf{a}$ must have a trans configuration $(J 12.1 \mathrm{~Hz})$. Changes in the chemical shift of hydrogens $\mathrm{H}-2$ and $\mathrm{H}-3$ for each isomer were also noted after the induced isomerization. Analyses of the integration values for $\mathrm{H}-2$ or $\mathrm{H}-3$ showed that formation of the cis isomer (Figure 4) is slow under our experimental conditions. A trans-cis interconversion rate of $6.7 \times 10^{-5} \mathrm{~s}^{-1}$ was estimated.

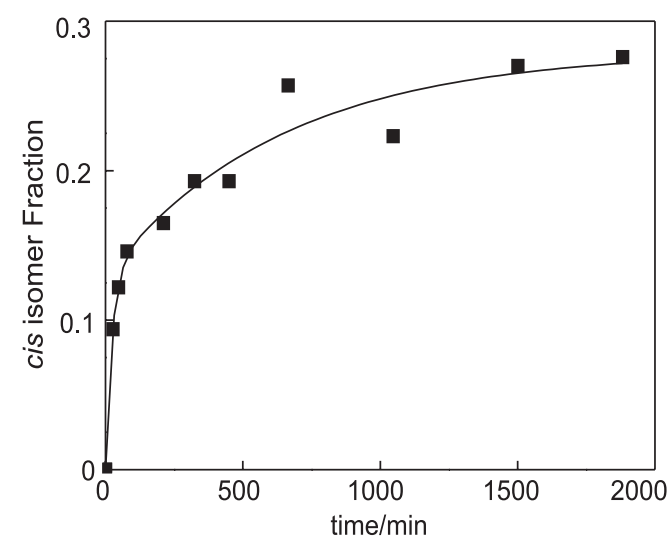

Figure 4. Formation of the cis isomer of compound $\mathbf{2}$ as a function of time.

After the irradiation reaction was completed, the mixture of the two isomers (2a and $\mathbf{2 b}$ ) was stored at low temperature for several months. The ${ }^{1} \mathrm{H}$ NMR spectrum of this mixture was then registered, showing that the cis isomer is highly stable. No interconversion took place during this period.

\section{Conclusions}

This work demonstrates the successful synthesis of methyl 3-(3-hydroxyphenoxy)acrylate (2), a new compound that is a potential precursor of the natural product 3-(3-hydroxyphenoxy)-2-propenal (1). By means of a photoisomerization reaction, we confirmed that the double bond present in $\mathbf{2}$ is trans (isomer $\mathbf{2 a}$ ).

\section{Experimental}

\section{General experimental procedures}

Dichloromethane and the common reagents resorcinol (1,3-dihydroxybenzene), triphenylphosphine and methyl propiolate are commercially available. Column chromatography separation was performed with silica gel 60 (70-230 mesh, Merck). All ${ }^{1} \mathrm{H}$ and ${ }^{13} \mathrm{C}$ NMR spectra were recorded at 400 and $75 \mathrm{MHz}$, respectively, using a Bruker DPX-400 instrument and chloroform- $d\left(\mathrm{CDCl}_{3}\right)$ or methyl- $d_{3}$ alcohol- $d\left(\mathrm{CD}_{3} \mathrm{OD}\right)$ as solvent; chemical shifts are in ppm downfield from a tetramethylsilane internal standard. UV-Vis absorption spectra were measured on a Hitachi U-3000 UV-Vis spectrophotometer. IR (KBr) spectra were measured on a Perkin Elmer Spectrum RX IFTIR System, and the most intense or representative bands are reported (in $\mathrm{cm}^{-1}$ ). GC-MS analyses were performed by EI ionization at $70 \mathrm{eV}$ on a Shimadzu GC/MS QP-2010 spectrometer. Elemental analyses were performed with a Carlo Erba instrument EA-1110. The rotating "merry-go-round" a pparatus used a Hanovia $400 \mathrm{~W}$ medium pressure mercury lamp, together with a cooling immersion well.

Methyl (2E)-3-(3-hydroxyphenoxy)acrylate (2a) and dimethyl (2E, 2'E)-3,3'-[1,3-phenylene-bis(oxy)] diacrylate (3)

A solution of methyl propiolate $(0.1651 \mathrm{~g}, 1.96 \mathrm{mmol})$ in dichloromethane $(5 \mathrm{~mL})$ was slowly added (10 min) to a stirred solution of triphenylphosphine $(0.3430 \mathrm{~g}$, $1.31 \mathrm{mmol})$ and resorcinol $(0.1440 \mathrm{~g}, 1.31 \mathrm{mmol})$ in dichloromethane $(30 \mathrm{~mL})$, cooled to $-5^{\circ} \mathrm{C}$. The ice bath was removed, and the reaction mixture was stirred at room temperature for $24 \mathrm{~h}$. The solvent was removed under reduced pressure, and the residue was purified by column chromatography on silica gel, using $n$-hexane and ethyl acetate in a 7:3 ratio as eluent, to afford a mixture of compounds $\mathbf{2 a}$ $(0.1651 \mathrm{~g}, 65 \%)$ and $\mathbf{3}(0.0546 \mathrm{~g}, 15 \%)$.

\section{Analytical data for compound $2 a$}

${ }^{1} \mathrm{H} \mathrm{NMR}\left(\mathrm{CDCl}_{3}, 400 \mathrm{MHz}\right) \delta 7.81(\mathrm{~d}, 1 \mathrm{H}, J 12.1 \mathrm{~Hz})$, 7.18 (t, 1H, J 8.3 Hz), 6.69 (ddd, 1H, J $1.0 \mathrm{~Hz}, J_{2} 2.3 \mathrm{~Hz}$, $\left.J_{3} 8.3 \mathrm{~Hz}\right), 6.59(\mathrm{~m}, 2 \mathrm{H}), 5.60(\mathrm{~d}, 1 \mathrm{H}, J 12.1 \mathrm{~Hz}), 3.75(\mathrm{~s}$, $3 \mathrm{H}) .{ }^{13} \mathrm{C} \mathrm{NMR}\left(\mathrm{CDCl}_{3}, 75 \mathrm{MHz}\right) \delta 168.7(\mathrm{C}), 159.5(\mathrm{CH})$, $157.5(\mathrm{C}), 156.9(\mathrm{C}), 130.6(\mathrm{CH}), 112.2(\mathrm{CH}), 109.6(\mathrm{CH})$, $105.4(\mathrm{CH}), 101.5(\mathrm{CH}), 51.7\left(\mathrm{CH}_{3}\right) . \mathrm{IR} \mathrm{v} / \mathrm{cm}^{-1}: 3394(\mathrm{O}-\mathrm{H})$, 3056 (C-H, aromatic), 1718 (C=O, ester), $1654(\mathrm{C}=\mathrm{C})$; 1266 (C-O). MS: $m / z$ (relative intensity) $194\left(\mathrm{M}^{+}, 98 \%\right)$, 163 (86), 135 (100), 121 (22), 107 (50), 94 (25), 81 (18), 69 (66), 65 (51), 53 (29). Anal. Calc. for $\mathrm{C}_{10} \mathrm{H}_{10} \mathrm{O}_{4}$ : C, 61.85; H, 5.19; O, 32.96. Found: C, 61.62; H, 4.98; O, 33.40.

\section{Analytical data for compound 3}

${ }^{1} \mathrm{H} \mathrm{NMR}(\mathrm{MeOD}, 400 \mathrm{MHz}) \delta 7.77(\mathrm{~d}, 2 \mathrm{H}, J 12.1 \mathrm{~Hz})$, 7.35 (t, 1H, J 8.3 Hz), 6.89 (dd, 2H, $J_{1} 2.4 \mathrm{~Hz}, J_{2} 8.3 \mathrm{~Hz}$ ), $6.84(\mathrm{t}, 1 \mathrm{H}, J, 2.3 \mathrm{~Hz}), 5.51(\mathrm{~d}, 2 \mathrm{H}, J 12.1 \mathrm{~Hz}), 3.52(\mathrm{~s}, 6 \mathrm{H})$. ${ }^{13} \mathrm{C}$ NMR (MeOD, $\left.75 \mathrm{MHz}\right) \delta 168.0(\mathrm{C}), 158.8(\mathrm{CH}), 157.4$ (C), $131.5(\mathrm{CH}), 114.1(\mathrm{CH}), 107.8(\mathrm{CH}), 102.4(\mathrm{CH}), 50.9$ $\left(\mathrm{CH}_{3}\right) . \mathrm{IR} v / \mathrm{cm}^{-1}: 3072$ (C-H, aromatic), 1714 (C=O, ester), $1652(\mathrm{C}=\mathrm{C}), 1260(\mathrm{C}-\mathrm{O})$. MS: $\mathrm{m} / \mathrm{z}$ (relative intensity) 278 (M+, 85\%), 247 (49), 219 (78), 215 (31), 205 (15), 187 
(100), 163 (39), 147 (16), 131 (18), 118 (31), 108 (47), 92 (18), 77 (17), 69 (18), 64 (26), 59 (47), 53 (15). Anal. Calc. for $\mathrm{C}_{14} \mathrm{H}_{14} \mathrm{O}_{6}: \mathrm{C}, 60.43 ; \mathrm{H}, 5.07 ; \mathrm{O}, 34.50$. Found: $\mathrm{C}$, $60.81 ; \mathrm{H}, 5.12 ; \mathrm{O}, 34.07$.

\section{Acknowledgments}

The authors thank Fundação de Amparo à Pesquisa do Estado de São Paulo (FAPESP) and Conselho Nacional de Desenvolvimento Científico e Tecnológico (CNPq) for financial support; Dr. Cláudio Francisco Tormena (IQUNICAMP), Dr. Timothy John Brocksom (DQ-UFSCar) and Dr. Gil Valdo José da Silva (DQ-FFCLRP-USP) are acknowledged for useful discussions.

\section{References}

1. Haynes, R. K.; Curr. Top. Med. Chem. 2006, 6, 509; Geldre, E. V.; Vergauwe, A.; Eeckhout, E. V.; Plant Mol. Biol. 1997, 33, 199.

2. Liu, C. Z.; Zhao, Y.; Wang, Y. C.; Appl. Microbiol. Biotechnol. 2006, 72, 11; Bilia, A. R.; Malgalhaes, P. M.; Bergonzi, M. C.; Vincieri, F. F.; Phytomedicine 2006, 13, 487.

3. Sy, L.-K.; Brown, G. D.; Phytochemistry 1999, 50, 781; Brown, G. D.; J. Nat. Prod. 1992, 55, 1756.

4. Shatar, S.; Altantsetseg, S.; Dung, N. X.; Ngoc, P. H.; Klinkby, N.; Leclercq, P. A.; J. Essential Oil Res. 2002, 14, 99; Shi, Y.; Li, Y.; Zhang, H.; Gaodeng Xuexiao Huaxue Xuebao 1992, 13, 1258. (CA 118:98083)
5. Dugave, C.; Demange, L.; Chem. Rev. 2003, 103, 2475.

6. Kakitami, T.; Kawatsu, T.; Kimura, A.; Yamada, A.; Yamoto, T.; Yamamoto, S.; J. Biol. Phys. 2002, 28, 367.

7. Clauss, R.; Hinz, W.; Hunter, R.; Synlett 1997, 1, 57.

8. Garcia-Exposito, E.; Gonzales-Moreno, R.; Martin-Vila, M.; Muray, E.; Rife, J.; Bourdelande, J. L.; Branchadell, V.; Ortuno, R. M.; J. Org. Chem. 2000, 65, 6958.

9. Yavari, I.; Hekmat-Shoar, R.; Zonousi, A.; Tetrahedron Lett. 1998, 39, 2391.

10. Oyamada, J.; Kitamura, T.; Tetrahedron 2006, 62, 6918 and references cited therein; Valizadeh, H.; Shockravi, A.; Tetrahedron Lett. 2005, 46, 3501 and references cited therein; Davies, S. G.; Mobbs, B. E.; Goodwin, C. J.; J. Chem. Soc., Perkin Trans. 1 1987, 2597; Sethna, S.; Phadke, R.; Org. React. 1953, 7, 1-58.

11. Trost, B. M.; Dake, G. R.; J. Am. Chem. Soc. 1997, 119, 7595.

12. Tae, J.; Kim, K-O.; Tetrahedron Lett. 2003, 44, 2125.

13. Hanédanian, M.; Loreau, O.; Taran, F.; Mioskowski, C.; Tetrahedron Lett. 2004, 45, 7035.

14. da Silva, R.; Donate, P. M.; da Silva, G. V. J.; Pedersoli, S.; Alemán, C.; J. Braz. Chem. Soc. 2005, 16, 626.

15. CRC Handbook of Organic Photochemistry; Scaiano, J. C., ed.; CRC Press: Florida, 1989, vol. 1.

Received: May 15, 2007

Published on the web: January 28, 2008

FAPESP helped in meeting the publication costs of this article. 